BMJ Open

Diabetes

Research

\& Care

\title{
Successful long-term weight loss among participants with diabetes receiving an intervention promoting an adapted Mediterranean-style dietary pattern: the Heart Healthy Lenoir Project
}

\author{
Genevieve G R Embree, ${ }^{1}$ Carmen D Samuel-Hodge, ${ }^{2,3}$ Larry F Johnston, ${ }^{3}$ \\ Beverly A Garcia, ${ }^{3}$ Ziya Gizlice, ${ }^{3}$ Kelly R Evenson, ${ }^{4}$ Darren A DeWalt, ${ }^{5}$ \\ Alice S Ammerman, ${ }^{2,3}$ Thomas C Keyserling ${ }^{3,5}$
}

To cite: Embree GGR,

Samuel-Hodge CD,

Johnston LF, et al.

Successful long-term weight loss among participants with diabetes receiving an intervention promoting an adapted Mediterranean-style dietary pattern: the Heart Healthy Lenoir Project. BMJ Open Diabetes Research and Care 2017;5:e000339.

doi:10.1136/bmjdrc-2016000339

Received 7 October 2016 Revised 2 February 2017 Accepted 20 February 2017

CrossMark

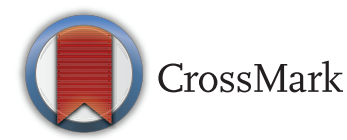

For numbered affiliations see end of article.

Correspondence to Dr Thomas C Keyserling; jato@med.unc.edu

\section{ABSTRACT}

Objective: To examine weight change by diabetes status among participants receiving a Mediterraneanstyle diet, physical activity, and weight loss intervention adapted for delivery in the southeastern USA, where rates of cardiovascular disease (CVD) are disproportionately high.

Research design and methods: The intervention included: Phase I (months 1-6), an individually tailored intervention promoting a Mediterranean-style dietary pattern and increased walking; Phase II (months 712), option of a 16-week weight loss intervention for those with $\mathrm{BMI} \geq 25 \mathrm{~kg} / \mathrm{m}^{2}$ offered as 16 weekly group sessions or 5 group sessions and 10 phone calls, or a lifestyle maintenance intervention; and Phase III (months 13-24), weight loss maintenance intervention for those losing $\geq 8$ pounds with all others receiving a lifestyle maintenance intervention. Weight change was assessed at 6,12, and 24-month follow-up.

Results: Baseline characteristics ( $n=339)$ : mean age 56, 77\% female, 65\% African-American, 124 (37\%) with diabetes; mean weight $103 \mathrm{~kg}$ for those with diabetes and $95 \mathrm{~kg}$ for those without. Among participants with diabetes, average weight change was $-1.2 \mathrm{~kg}(95 \% \mathrm{Cl}-2.1$ to -0.4$)$ at 6 months $(\mathrm{n}=92)$, $-1.5 \mathrm{~kg}(95 \% \mathrm{Cl}-2.9$ to -0.2$)$ at 12 months $(\mathrm{n}=96)$, and $-3.7 \mathrm{~kg}(95 \% \mathrm{Cl}-5.2$ to -2.1$)$ at 24 months $(\mathrm{n}=93)$. Among those without diabetes, weight change was $-0.4 \mathrm{~kg}(95 \% \mathrm{Cl}-1.4$ to 0.6$)$ at 24 months $(n=154)$.

Conclusions: Participants with diabetes experienced sustained weight loss at 24-month follow-up. High-risk US populations with diabetes may experience clinically important weight loss from this type of lifestyle intervention.

Trial registration number: NCT01433484.

\section{INTRODUCTION}

Weight loss, defined by the American Diabetes Association as a sustained reduction of $5 \%$ of initial body weight, ${ }^{1}$ is recommended for overweight and obese patients

\section{Significance of this study}

What is already known about this subject?

Though not well studied in the USA, particularly among low-income and minority populations, a Mediterranean-style dietary pattern can reduce the risk for cardiovascular disease (CVD) among those with and without type 2 diabetes and has been shown in some studies to be associated with maintenance of weight loss.

\section{What are the new findings?}

We developed and evaluated a lifestyle and weight loss intervention for low-income and minority residents of eastern North Carolina, with a major focus on implementing a culturally adapted Mediterranean-style dietary pattern while also promoting physical activity. Among study participants with diabetes, the intervention was well received and associated with sustained weight loss at 24-month follow-up.

How might these results change the focus of research or clinical practice?

This study demonstrates high acceptability of a Mediterranean-style dietary pattern among lowincome and minority populations residing in eastern North Carolina and appears to be promising as a weight loss intervention for participants with diabetes. This dietary pattern and type of intervention should be evaluated in randomized controlled trials to further assess the intervention's effectiveness at improving CVD risk factors, yielding sustained weight loss, and reducing CVD events.

with type 2 diabetes, while others have noted that weight loss as small as $2 \mathrm{~kg}$ appears to provide clinical benefit. ${ }^{2}$ However, weight loss is difficult to achieve and harder to sustain; and in general, individuals with diabetes have a harder time losing weight and maintaining weight loss, when compared 
with those without diabetes. ${ }^{3}$ This is especially true for high risk groups such as African-American women with type 2 diabetes. ${ }^{4}$ For example, in the Action for Health in Diabetes (Look AHEAD) trial, ${ }^{5}$ among female participants with diabetes, the year-1 weight loss was $6.8 \%$ for African-Americans compared with $9.1 \%$ for non-Hispanic whites. Thus, improved approaches for promoting weight loss are needed for patients with diabetes and especially for groups at higher risk for obesity and diabetes such as African-American women.

Some have argued that a variety of weight loss dietary patterns are acceptable if they lead to weight loss. ${ }^{6}$ However, as patients with type 2 diabetes are at very high risk for cardiovascular disease (CVD), consideration should be given to advocating a weight loss dietary pattern that also reduces CVD risk. When a Mediterranean diet pattern, supplemented with olive oil or nuts, was evaluated in the Prevención con Dieta Mediterránea (PREDIMED) randomized trial, ${ }^{7}$ there was a $30 \%$ reduction in CVD risk among participants with and without diabetes. This contrasts with the lower fat weight loss diet evaluated in Look AHEAD, ${ }^{8}$ which led to significant weight loss but did not reduce CVD risk.

Attention to dietary pattern as a critical component of weight loss diets may be even more important for populations at very high risk for CVD, such as minority populations and those residing in the 'stroke belt' of the southeastern USA, where CVD rates are substantially higher compared with national levels. ${ }^{9}$ Thus, we developed and evaluated a lifestyle and weight loss intervention for residents of eastern North Carolina, with a major focus on implementing a culturally adapted Mediterranean-style dietary pattern while also promoting physical activity. In this paper, we report the intervention's effect on diet and physical activity behaviors, CVD risk factors, and weight loss through 24 months of follow-up by participants' diabetes status.

\section{RESEARCH DESIGN AND METHODS \\ Study overview}

The Heart Healthy Lenoir (HHL) Project was a collaborative research effort designed to reduce CVD risk and disparities in CVD risk among Lenoir County, North Carolina residents, as previously described. ${ }^{10}{ }^{11}$ It was funded by the National Heart, Lung, and Blood Institute (NHLBI) as part of an initiative with the National Cancer Institute 'to develop and test multilevel interventions to reduce health disparities. ${ }^{, 12}$ This paper focuses on participants who took part in the HHL lifestyle study, ${ }^{11}$ one of three coordinated HHL studies which also included a study to improve high blood pressure (BP) management at local practices and a study examining associations between genetic markers and change in CVD risk factors. These studies were conducted in Lenoir County because of its location in the 'stroke belt' ${ }^{9}$ of eastern North Carolina, where rates of
CVD are higher than state and national averages ${ }^{13}$ and because it has a large minority population (40\% African-American) that experiences disproportionally higher rates of CVD. ${ }^{14}$ The HHL lifestyle study was designed and conducted with input from a local community advisory committee ${ }^{10}$ and was approved and monitored by the University of North Carolina's Institutional Review Board. Data were collected between 20 September, 2011 and 7 November, 2014.

The lifestyle study consisted of three phases as shown in figure 1, which depicts the three sequential phases of the study and the number of participants with and without diabetes who took part in each component of the intervention. Phase I, which lasted 6 months and was the same for all study participants, focused on improving diet quality and increasing physical activity. In Phase II, which also lasted 6 months, participants with a body mass index $(\mathrm{BMI}) \geq 25 \mathrm{~kg} / \mathrm{m}^{2}$ were offered an intensive weight loss intervention while those with a $\mathrm{BMI}<25 \mathrm{~kg}$ / $\mathrm{m}^{2}$ and those who declined the weight loss intervention received a maintenance of lifestyle intervention. In Phase III, participants who lost $\geq 8 \mathrm{lbs}(3.6 \mathrm{~kg})$ at the conclusion of Phase II were invited to take part in a yearlong, randomized controlled trial (RCT), comparing a more intensive and less intensive maintenance of weight loss intervention; a year-long maintenance of lifestyle intervention was given to those who did not take part in the RCT. As prior RCTs conducted by our research team $^{15-18}$ have shown that similar formats of lifestyle and weight loss interventions are effective in improving lifestyle and achieving weight loss among low socioeconomic status participants, we did not include a control group for Phases I and II of this study. Furthermore, our community advisory committee strongly encouraged a study design in which all participants received 'active treatment.'

\section{Participants}

The enrollment goal for this study, based on having an adequate sample for the Phase III maintenance of weight loss RCT, was 350 with about 150 participants recruited from the community and 200 from the high BP study, as previously described. ${ }^{11}{ }^{19}$ Criteria for screening from the community were age $\geq 18$ years and interest in improving lifestyle behaviors to reduce CVD risk. Screening criteria for the high BP study were age $\geq 18$, being an established patient at a participating practice, and systolic $\mathrm{BP} \geq 150 \mathrm{mmHg}$ when assessed during routine care within the prior 12 months.

After obtaining verbal informed consent, research staff conducted phone interviews to screen potential participants. ${ }^{11}$ If eligibility criteria were met, participants were invited to an enrollment visit at a central research office or at participating clinics. Written informed consent was obtained prior to collecting baseline measures. Participants attending the enrollment visit for the high BP study were invited to also take part in the lifestyle study until 200 agreed to do so. 


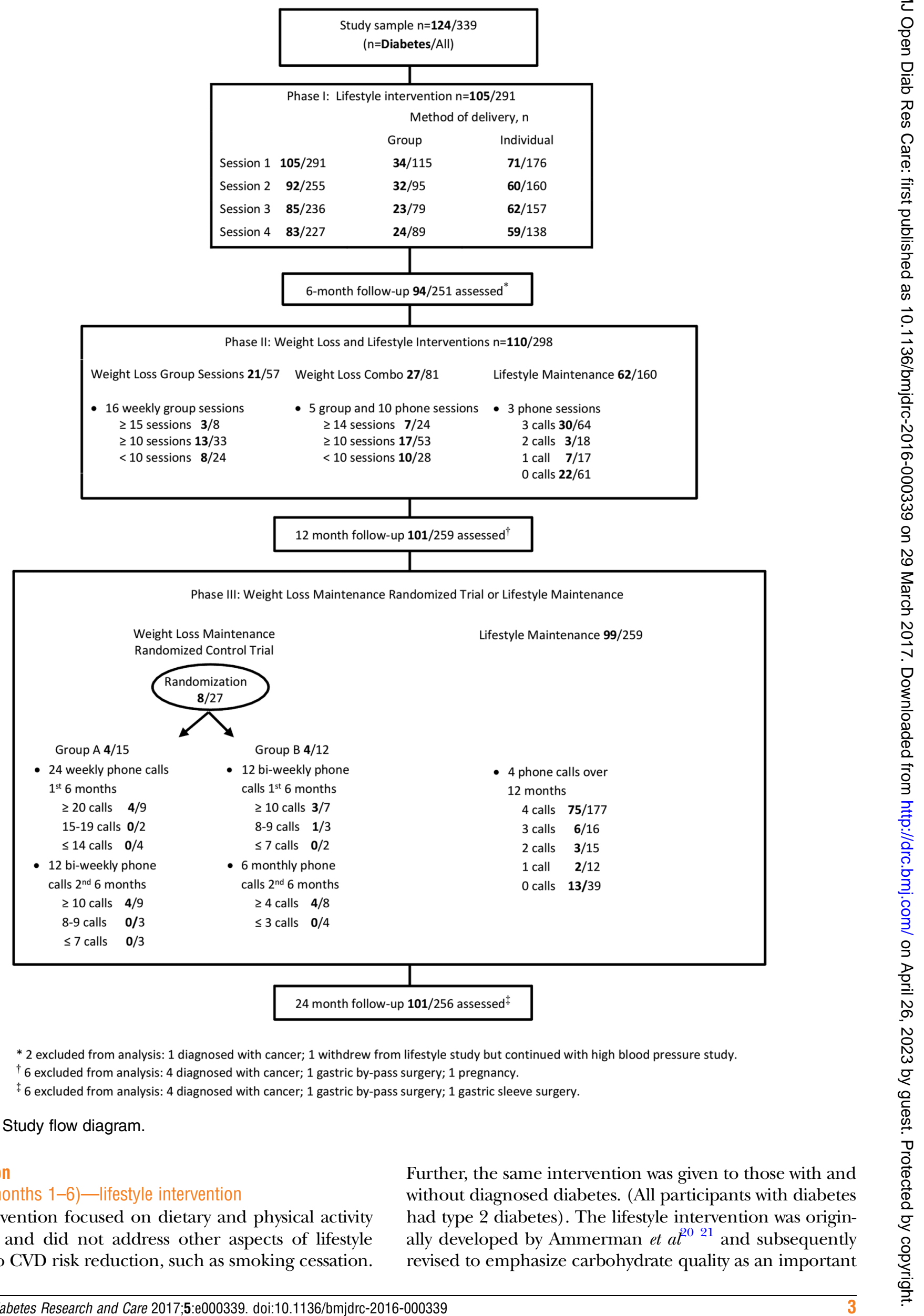


component of a heart-healthy diet. ${ }^{15}$ Consistent with the evolving literature suggesting frequent consumption of food with high-quality fats (polyunsaturated and monounsaturated fats primarily from plant sources and fish) is also important in reducing CVD risk in those with and without diabetes, ${ }^{72-26}$ this study's dietary intervention was further modified to include a major focus on improving dietary fat quality. These changes rendered the HHL lifestyle intervention dietary pattern very similar to the PREDIMED study's nut intervention arm diet; ${ }^{7}$ therefore, the dietary pattern was termed 'Med-South' because of its intended use in the southeastern USA.

The intervention format and content have been previously published and described in detail. ${ }^{11}$ Phase I included four monthly sessions delivered by a trained counselor administered as hour-long individual counseling sessions or 90 min group sessions given at a centrally located research office or participating clinic. Participants chose their preferred counseling format. About $75 \%$ of counseling time was devoted to dietary behaviors with the rest focusing on physical activity. Dietary counseling included culturally relevant content to improve fat quality (such as increasing consumption of nuts, full-fat salad dressings and mayonnaise, and vegetable oils), increase fruit and vegetable consumption, promote fish and poultry intake while reducing red and processed meat intake, and minimize consumption of sugar-sweetened beverages, high-sugar-content desserts, and snacks. Physical activity counseling focused mostly on walking with a recommended goal of at least $7500 \mathrm{steps} /$ day or $\geq 30 \mathrm{~min} /$ day of physical activity on $\geq 5$ days/week. Spouses and friends were invited to attend the counseling intervention sessions. When participants could not physically attend counseling sessions, telephone counseling was offered. Participants also received a pedometer and activity logs to self-monitor physical activity as well as a listing of local community resources that promoted healthy eating (eg, farmers' markets) and physical activity (eg, community parks). Those participants who were co-enrolled in the high BP study received a home $\mathrm{BP}$ monitor and were instructed to measure their BP at least three times per week. They also received monthly phone calls for a year, primarily promoting BP medication adherence.

During counseling sessions, participants worked with their counselor to create individually tailored action plans to improve dietary and physical activity behaviors. Dietary and physical activity tips were tailored to problematic lifestyle behaviors assessed on the baseline lifestyle questionnaire. Dietary tips included recipe suggestions from a southern-style cookbook that was given to all participants. At the beginning of sessions 24 , the counselor and participants reviewed progress made towards previously stated goals.

\section{Phase II (months 7 through 12)—weight loss and maintenance of lifestyle interventions}

Participants with a $\mathrm{BMI} \geq 25 \mathrm{~kg} / \mathrm{m}^{2}$ could choose to take part in the weight loss intervention. Those who were not eligible for the weight loss intervention $\left(\mathrm{BMI}<25 \mathrm{~kg} / \mathrm{m}^{2}\right)$ and those who declined the intervention received a maintenance of lifestyle intervention consisting of three phone calls, as previously described. ${ }^{11}$ The weight loss intervention was offered in two formats over $\sim 16$ weeks: 16 weekly group sessions as previously tested, ${ }^{16} 1827$ or five group sessions plus 10 phone contacts (combination intervention), as recently described. ${ }^{11}$ The major modification from the previously tested weight loss intervention was the focus on the Med-South dietary pattern and addition of newer evidence-based behavioral components (eg, daily self-weighing). ${ }^{28}$

\section{Phase III (13-24 months) —weight loss and lifestyle maintenance interventions}

Participants who took part in the Phase II weight loss intervention and lost $\geq 8 \mathrm{lbs}(3.6 \mathrm{~kg})$ were invited to take part in the maintenance of weight loss RCT. All other study participants received brief, quarterly maintenance of lifestyle intervention phone calls (similar to Phase II), as previously described. ${ }^{11}$ For the maintenance of weight loss RCT, participants were randomized 1:1 to receive either 36 phone contacts (24 weekly calls over 6 months followed by 12 biweekly calls over 6 months; more intensive intervention) or 18 phone contacts (12 biweekly calls over 6 months followed by 6 monthly calls over 6 months; less intensive intervention).

\section{Measures}

Outcome measures were assessed at baseline, 6, 12, and 24 months. Previously validated questionnaires were administered to assess lifestyle change including the Dietary Risk Assessment (DRA) which assessed overall diet quality, ${ }^{20}{ }^{29}$ the brief Block fruit and vegetable questionnaire, ${ }^{30}$ a dietary fat quality screener, ${ }^{31}$ and a questionnaire to assess walking and overall physical activity. ${ }^{32} 33$ In addition, the SF-12 (SF-12 instrument, Quality Metric, Lincoln, RI) was administered to assess quality of life. Weight was assessed by electronic scale (Seca 874, Seca, Hanover, MD) as the average of two measures to the closest tenth pound. Height was measured with a portable stadiometer at baseline only. BP was calculated as the average of three measurements recorded at $60 \mathrm{~s}$ intervals (Omron HEM-907XL, Omron Healthcare, Lake Forest, IL) after being seated for 5 min. Blood lipids and glycated hemoglobin (A1c) were assessed by a commercial laboratory (LabCorp, Burlington, North Carolina, USA). At follow-up measurement visits, questionnaires were administered to assess acceptability of the intervention and adverse outcomes. Participants received compensation for measurement visits: $\$ 40$ for enrollment, $\$ 25$ for 6 and 12-month visits, and $\$ 30$ for the 24-month visit.

\section{Sample size and statistical analysis}

The enrollment goal of 350 participants was based on having a sufficient sample $(\mathrm{N}=100)$ for the embedded RCT of weight loss maintenance. ${ }^{11}$ In addition, the 
overall sample of 350 was considered sufficient to describe the primary objective of the lifestyle intervention to improve diet quality at 6-month follow-up, and the major secondary objectives of improved diet quality, physical activity, and weight loss at 12 and 24-month follow-up.

Sample characteristics were summarized using descriptive statistics, with subgroups by diabetes status and race. Outcomes were assessed using pre-post changes by diabetes status and race with paired t-tests for continuous outcomes, McNemar's tests for binary outcomes, and $\chi^{2}$ tests for subgroup analysis when appropriate. Data are reported for returnees at follow-up without imputation for missing data. As described, ${ }^{11}$ among all study participants, weight loss was substantially less than anticipated and observed in our prior weight loss studies. ${ }^{16}{ }^{18}$ Only 27 participants overall (eight with diabetes) took part in the maintenance of weight loss RCT. Given this small number, weight loss results are reported in the aggregate and not separately for those who took part in the RCT. Because age, race, sex, education, and baseline weight are potential confounders for weight loss, a linear regression analysis was conducted adjusting for these variables. Participants who became pregnant, had bariatric surgery, or were diagnosed with cancer (excluding non-melanoma skin cancer or localized breast or prostate cancer diagnosed by screening tests) were excluded from analysis (eight overall, four with diabetes). SAS V.9.3 was used for analysis.

\section{RESULTS}

\section{Baseline characteristics}

As outlined in detail elsewhere, ${ }^{11}$ of 642 individuals assessed as eligible for this study, $366(57 \%)$ attended the enrollment visit and 339 (53\%) completed all baseline measurements and comprised the study sample, including 134 recruited from the community and 205 from the clinic-based high BP study. Participants' baseline characteristics, by diabetes status then further categorized by race, are outlined in table 1 .

A total of $124(37 \%)$ participants had diabetes. The overall average age was 56 years; participants with diabetes were older on average than those without diabetes (59 vs 54 years). Men, particularly African-American men, were underrepresented in the sample. More than half of participants did not have any college education. Those without diabetes and whites were more likely to be married or living with a partner compared with others. Most participants had health insurance $(74 \%)$ and this did not vary by diabetes status or race. Those with diabetes were more likely to be unemployed due to health reasons $(31 \%$ vs $14 \%)$ and less likely to be currently employed full-time or part-time ( $34 \%$ vs $58 \%$ ). Median annual household income was $<\$ 40000$ overall and $<\$ 20000$ among participants with diabetes.

In terms of CVD risk factors, reported rates of hypertension were very high in the study ( $86 \%$ overall), which may be largely attributed to how participants were selected. Participants with diabetes were more likely to report a history of hypertension (98\% compared with $79 \%)$ and African-Americans reported higher rates of hypertension than whites within each subgroup. Participants with diabetes also reported higher rates of prior coronary heart disease and CVD.

At baseline, overall diet quality and fat quality were similar across diabetes status and race, while participants with diabetes had slightly higher fruit and vegetable consumption (average 3.7 compared with 3.3 servings/day). Participants without diabetes reported much higher total walking and total activity time at baseline (mean 105 and 171 min per week, respectively, compared with 67 and 112 min per week, respectively, among those with diabetes). Participants with diabetes weighed more on average than those without diabetes (103 kg compared with $95 \mathrm{~kg}$ ). Systolic BP was similar across all categories, with a somewhat higher average for African-Americans than whites (138 mmHg compared with $131 \mathrm{mmHg}$ ) among participants with diabetes. Among those with diabetes, African-American participants had higher hemoglobin Alc percentage at baseline than whites $(8.0 \%$ compared with $7.6 \%$ ).

\section{Outcomes}

Figure 1 depicts the three sequential phases of the study and the number of participants with and without diabetes that took part in each component of the intervention and returned for follow-up. Follow-up rates at 6, 12, and 24 months were $\sim 75 \%$ and were similar between participants with and without diabetes. Lifestyle outcomes are shown in table 2.

Overall diet quality, as assessed by the DRA total score, improved by about 4 points at 6 -month follow-up for all participants and each of the subgroups. Improvement in DRA total score was maintained at 12 and 24 months compared with baseline among all subgroups except white participants with diabetes. Fat quality score improved by 1.4 points on average at 6 months with no significant difference between subgroups by race or diabetes status, but this improvement was attenuated over time for participants with diabetes. Only participants without diabetes reported a statistically significant increase in fruit and vegetable servings per day at 6,12 , and 24-month follow-up. The improvement in the summary score for drinks, desserts, and snacks was higher among African-American participants with and without diabetes compared with whites. Increased walking time was sustained at 24 months among participants with diabetes and among African-Americans with diabetes.

Physiological outcomes are shown in table 3.

Among all participants, there was a statistically significant reduction in systolic BP of about 6 to $7 \mathrm{mmHg}$ across all follow-up time points. The reduction was similar for those with diabetes and larger for African-Americans with diabetes compared with whites. 


\begin{tabular}{|c|c|c|c|c|c|c|c|}
\hline \multirow[b]{2}{*}{ Characteristics } & \multirow[b]{2}{*}{$\begin{array}{l}\text { Overall } \\
n=339\end{array}$} & \multicolumn{3}{|l|}{ Diabetes } & \multicolumn{3}{|c|}{ No Diabetes } \\
\hline & & $\begin{array}{l}\text { All } \\
n=124\end{array}$ & $\begin{array}{l}\text { African-American } \\
\mathrm{n}=89\end{array}$ & $\begin{array}{l}\text { White } \\
\mathrm{n}=34\end{array}$ & $\begin{array}{l}\text { All } \\
n=215\end{array}$ & $\begin{array}{l}\text { African-American } \\
n=130\end{array}$ & $\begin{array}{l}\text { White } \\
\mathrm{n}=83\end{array}$ \\
\hline \multicolumn{8}{|l|}{ Demographics } \\
\hline Age, mean (SE) & $56(0.6)$ & $59(0.9)$ & $59(1.1)$ & $61(1.7)$ & $54(0.8)$ & $51(1.1)$ & $57(1.2)$ \\
\hline Female & $260(77)$ & $93(75)$ & $70(79)$ & $22(65)$ & $167(78)$ & $111(85)$ & $54(65)$ \\
\hline \multicolumn{8}{|l|}{ Race } \\
\hline African-American & $219(65)$ & 89 (72) & & & $130(61)$ & & \\
\hline White & $117(35)$ & $34(28)$ & & & $83(39)$ & & \\
\hline \multicolumn{8}{|l|}{ Education, years } \\
\hline$\leq 8$ (middle school or less) & $16(5)$ & $7(6)$ & $4(5)$ & $3(9)$ & $9(4)$ & $7(5)$ & $2(2)$ \\
\hline$\overline{9}-11$ (some high school) & 45 (13) & $25(20)$ & $22(25)$ & $2(6)$ & $20(9)$ & $13(10)$ & 7 (8) \\
\hline 12 (high school graduate) & $128(38)$ & $46(37)$ & $36(40)$ & $10(29)$ & $82(38)$ & $58(45)$ & $24(29)$ \\
\hline $13-15$ (some college) & 79 (23) & 24 (19) & $16(18)$ & $8(24)$ & $55(26)$ & 29 (22) & $25(30)$ \\
\hline 16 (college graduate) & 49 (14) & $14(11)$ & $9(10)$ & $5(15)$ & $35(16)$ & $17(13)$ & $17(21)$ \\
\hline$>16$ (graduate school) & $22(7)$ & $8(7)$ & $2(2)$ & $6(18)$ & $14(7)$ & $6(5)$ & $8(10)$ \\
\hline Education: high school or less & $189(56)$ & $78(63)$ & $62(70)$ & $15(44)$ & $111(52)$ & $78(60)$ & $33(40)$ \\
\hline \multicolumn{8}{|l|}{ Marital status } \\
\hline Married or living with a partner & $159(47)$ & $51(41)$ & $32(36)$ & $19(56)$ & $108(50)$ & $50(39)$ & $57(69)$ \\
\hline Other & $180(53)$ & $73(59)$ & $57(64)$ & $15(44)$ & $107(50)$ & $80(62)$ & $26(31)$ \\
\hline Currently have health insurance & $251(74)$ & $94(76)$ & $68(76)$ & $25(74)$ & $157(73)$ & $88(68)$ & $67(81)$ \\
\hline \multicolumn{8}{|l|}{ Current employment } \\
\hline Working full time & $124(37)$ & $25(20)$ & $18(20)$ & $7(21)$ & $99(46)$ & 64 (49) & $33(40)$ \\
\hline Working part time & $42(12)$ & $17(14)$ & $14(16)$ & $2(6)$ & $25(12)$ & $17(13)$ & $8(10)$ \\
\hline Do not work due to health reasons & $69(20)$ & $38(31)$ & $26(29)$ & $12(35)$ & $31(14)$ & $17(13)$ & $14(17)$ \\
\hline Retired & $53(16)$ & $26(21)$ & $18(20)$ & $8(24)$ & $27(13)$ & $8(6)$ & $19(23)$ \\
\hline Other & $51(15)$ & $18(14)$ & $13(15)$ & $5(15)$ & $33(15)$ & $24(19)$ & $9(11)$ \\
\hline \multicolumn{8}{|l|}{ Annual household income } \\
\hline$<\$ 10000$ & $62(20)$ & $31(29)$ & $24(32)$ & $6(18)$ & $31(16)$ & $26(22)$ & $5(7)$ \\
\hline$\$ 10000$ to $<\$ 20000$ & 64 (21) & $28(26)$ & $23(31)$ & $5(15)$ & $36(18)$ & 22 (19) & $14(18)$ \\
\hline$\$ 20000$ to $<\$ 40000$ & $84(28)$ & $29(27)$ & $20(27)$ & $9(27)$ & $55(28)$ & 40 (34) & $14(18)$ \\
\hline$\$ 40000$ to $<\$ 60000$ & $33(11)$ & $9(8)$ & $3(4)$ & $6(18)$ & $24(12)$ & $12(10)$ & $12(16)$ \\
\hline$\$ 60000$ to $<\$ 80000$ & $27(9)$ & $9(8)$ & $4(5)$ & $5(15)$ & $18(9)$ & $9(8)$ & $9(12)$ \\
\hline$\geq \$ 80000$ & $34(11)$ & $2(2)$ & $0(0)$ & $2(6)$ & $32(15)$ & $10(8)$ & $22(29)$ \\
\hline \multicolumn{8}{|l|}{$C V D$ and risk factors for $C V D$} \\
\hline Known coronary heart disease & $49(14)$ & $28(23)$ & $20(23)$ & $8(24)$ & $21(10)$ & $10(8)$ & $11(13)$ \\
\hline Known cardiovascular disease & $62(18)$ & $33(27)$ & $23(26)$ & $10(29)$ & 29 (13) & $14(11)$ & $15(18)$ \\
\hline Hypertension & $291(86)$ & $121(98)$ & 88 (99) & $32(94)$ & $170(79)$ & 107 (82) & $63(76)$ \\
\hline \multicolumn{8}{|l|}{ Cholesterol } \\
\hline High ( $\geq 240 \mathrm{mg} / \mathrm{dL})$ & $187(56)$ & $82(67)$ & $57(65)$ & $24(71)$ & $105(49)$ & $53(42)$ & $52(63)$ \\
\hline Borderline (200-239 mg/dL) & $46(14)$ & $8(7)$ & $7(8)$ & $1(3)$ & $38(18)$ & $26(21)$ & $11(13)$ \\
\hline Desirable (<200 mg/dL) & $102(30)$ & $33(27)$ & $24(27)$ & $9(27)$ & $69(33)$ & $48(38)$ & $20(24)$ \\
\hline Diabetes & $124(37)$ & & & & & & \\
\hline Current cigarette smoker & $54(16)$ & $21(17)$ & $17(19)$ & $4(12)$ & $33(15)$ & $20(15)$ & $13(16)$ \\
\hline $\begin{array}{l}\text { Packs of cigarettes smoked per day, } \\
\text { mean (SE) for current smokers }\end{array}$ & $0.7(0.1)$ & $0.6(0.1)$ & $0.6(0.1)$ & $0.8(0.2)$ & $0.7(0.1)$ & $0.6(0.1)$ & $0.9(0.2)$ \\
\hline
\end{tabular}




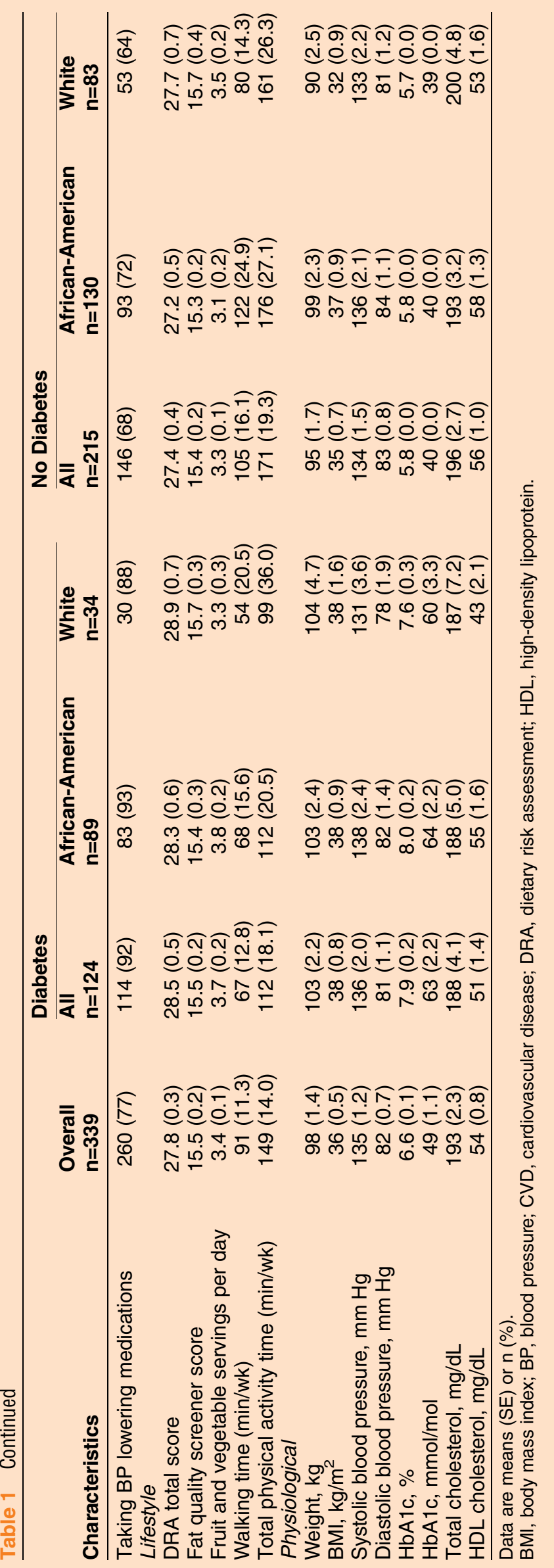

Outcomes for diastolic BP were similar. Of note, there was very little change in participants' use of blood measure medication at follow-up (data not shown). For those with diabetes, the number reporting use of $\mathrm{BP}$ medication was unchanged at 6-month, one less at 12-month, and two less at 24-month follow-up. For those without diabetes, use increased by one at 6 , two at 12 , and two at 24-month follow-up. There was a trend toward significant improvement in hemoglobin A1c at 12 months among participants with diabetes $(-0.30 \%$ (95\% CI -0.63 to 0.02$) /-3.3 \mathrm{mmol} / \mathrm{mol}(95 \%$ CI -6.9 to 0.2$), \mathrm{p}=0.07)$. Overall, there was a small decrease in total and HDL cholesterol.

Weight loss was a major outcome of interest. Participants with diabetes had significant, sustained, and progressive weight loss compared with baseline at 6,12 , and 24 months (mean $-1.2 \mathrm{~kg},-1.5 \mathrm{~kg}$, and $-3.7 \mathrm{~kg}$, respectively) across all intervention groups. White participants with diabetes had greater weight loss than African-American participants with diabetes. Weight change for participants with diabetes at 12-month follow-up (data not shown) by intervention group selected at the start of the HHL weight program (start of Phase II) was: $-3.9 \mathrm{~kg}(95 \% \mathrm{CI}-7.4$ to $-0.4, \mathrm{p}=0.03)$ for the group weight loss program $(\mathrm{n}=17) ;-2.6 \mathrm{~kg}(95 \%$ CI -5.0 to $-0.2, p=0.03$ ) for the combination weight loss program $(\mathrm{n}=27)$; and $-0.2 \mathrm{~kg}(95 \%$ CI -2.0 to 1.6 , $\mathrm{p}=0.81)$ for the maintenance of lifestyle intervention program (n=52). At 24-month follow-up (data not shown), it was $-5.2 \mathrm{~kg}$ (95\% CI -9.6 to $-0.8, \mathrm{p}=0.2)$ for the group weight loss program $(\mathrm{n}=18) ;-2.2 \mathrm{~kg}(95 \%$ CI -4.6 to $0.1, \mathrm{p}=0.06$ ) for the combination weight loss program $(\mathrm{n}=25)$; and $-3.8 \mathrm{~kg}(95 \%$ CI -5.9 to -1.8 , $\mathrm{p}<0.001)$ for the maintenance of lifestyle intervention program $(n=50)$. After adjusting for age, race, sex, education, and baseline weight, only participants with diabetes had significant sustained weight loss at 24 months $(p<0.0001)$ and participants with diabetes had significantly more weight loss on average than participants without diabetes $(\mathrm{p}=0.01)$.

Figure 2 depicts weight change (loss and gain) at follow-up by diabetes status with cut points for weight change from baseline of $\geq 2.5, \geq 5$, and $\geq 7.5 \%$. Consistent with mean weight loss, a greater proportion of participants with diabetes demonstrated substantially greater weight loss than gain at these time points, especially at 24 months. At 24 months, 18 participants (20\%) lost more than 7.5\% body weight while none gained this amount. For those without diabetes, the percentages of those who lost and gained weight at 24 months were similar.

From baseline to 24-month follow-up, 32 participants (34\%) with diabetes lost at least $5 \%$ body weight compared with 25 participants $(16 \%)$ without diabetes. Percentages for $\geq 5 \%$ weight loss were similar between African-Americans and whites with diabetes; however, more African-American participants without diabetes achieved $\geq 5 \%$ weight loss at 24 months than whites without diabetes (18\% compared with $10 \%$, respectively). 
Table 2 Change in lifestyle outcomes by diabetes status and race from baseline to 6, 12, and 24 months

\begin{tabular}{|c|c|c|c|c|c|c|}
\hline Outcome & $\mathbf{N}$ & $\begin{array}{l}\text { Phase } 1 \\
\text { Baseline to } 6 \\
\text { months } \\
\text { Mean, } 95 \% \mathrm{Cl}\end{array}$ & $\mathbf{N}$ & $\begin{array}{l}\text { Phase } 2 \\
\text { Baseline to } 12 \\
\text { months } \\
\text { Mean, } 95 \% \mathrm{Cl}\end{array}$ & $\mathbf{N}$ & $\begin{array}{l}\text { Phase } 3 \\
\text { Baseline to } 24 \\
\text { months } \\
\text { Mean, } 95 \% \mathrm{Cl}\end{array}$ \\
\hline \multicolumn{7}{|l|}{ Dietary } \\
\hline DRA total score & 235 & $4.4(3.7 \text { to } 5.0)^{\star \star \star}$ & 227 & $3.3(2.5 \text { to } 4.0)^{\star \star \star}$ & 226 & $3.0(2.3 \text { to } 3.6)^{\star \star *}$ \\
\hline Diabetes (all) & 86 & $4.2(3.1 \text { to } 5.3)^{\star \star \star}$ & 86 & $3.0(1.8 \text { to } 4.2)^{\star \star \star}$ & 84 & $2.0(1.0 \text { to } 3.1)^{* * *}$ \\
\hline African-American & 60 & $4.4(2.9 \text { to } 5.9)^{\star \star \star}$ & 63 & $3.8(2.3 \text { to } 5.3)^{\star \star \star}$ & 62 & $2.5(1.2 \text { to } 3.7)^{* * *}$ \\
\hline White & 25 & $4.0(2.6 \text { to } 5.4)^{\star \star \star}$ & 22 & $1.1(-0.6$ to 2.8$)$ & 21 & $0.7(-1.3$ to 2.7$)$ \\
\hline No diabetes (all) & 149 & $4.4(3.6 \text { to } 5.3)^{\star \star \star}$ & 141 & $3.4(2.5 \text { to } 4.4)^{\star \star \star}$ & 142 & $3.5(2.7 \text { to } 4.3)^{* * *}$ \\
\hline African-American & 95 & $4.7(3.7 \text { to } 5.7)^{\star \star \star}$ & 93 & $4.1(3.0 \text { to } 5.3)^{\star \star \star}$ & 96 & $3.3(2.3 \text { to } 4.4)^{\star \star *}$ \\
\hline White & 52 & $3.9(2.5 \text { to } 5.4)^{\star \star \star}$ & 47 & $2.0(0.3 \text { to } 3.7)^{*}$ & 45 & $3.7(2.5 \text { to } 5.0)^{\star \star *}$ \\
\hline Fat quality screener score & 229 & $1.4(1.0 \text { to } 1.8)^{\star \star \star}$ & 225 & $1.0(0.6 \text { to } 1.3)^{\star \star \star *}$ & 224 & $0.7(0.3 \text { to } 1.1)^{* * *}$ \\
\hline Diabetes (all) & 84 & $1.3(0.7 \text { to } 2.0)^{\star \star \star}$ & 85 & $1.2(0.6 \text { to } 1.8)^{\star \star \star}$ & 83 & $0.3(-0.3$ to 1.0$)$ \\
\hline African-American & 58 & $1.2(0.4 \text { to } 2.0)^{\star \star}$ & 62 & $1.5(0.8 \text { to } 2.2)^{\star \star \star}$ & 61 & $0.4(-0.3$ to 1.1$)$ \\
\hline White & 25 & $1.6(0.4 \text { to } 2.7)^{\star *}$ & 22 & $0.4(-0.3$ to 1.2$)$ & 21 & $0.1(-1.2$ to 1.5$)$ \\
\hline No Diabetes (all) & 145 & $1.4(1.0 \text { to } 1.9)^{\star \star \star}$ & 140 & $0.8(0.4 \text { to } 1.3)^{\star \star \star}$ & 141 & $0.8(0.4 \text { to } 1.3)^{* * *}$ \\
\hline African-American & 92 & $1.5(1.0 \text { to } 2.1)^{\star \star \star}$ & 92 & $1.1(0.6 \text { to } 1.6)^{\star \star \star}$ & 95 & $0.8(0.3 \text { to } 1.4)^{\star \star}$ \\
\hline White & 51 & $1.2(0.5 \text { to } 2.0)^{\star \star}$ & 47 & $0.4(-0.4$ to 1.2$)$ & 45 & $0.9(-0.1$ to 1.9$)$ \\
\hline Fruit and vegetable servings per day & 249 & $0.3(0.1 \text { to } 0.5)^{\star}$ & 253 & $0.5(0.3 \text { to } 0.8)^{\star \star \star}$ & 250 & $0.4(0.2 \text { to } 0.6)^{* * *}$ \\
\hline Diabetes (all) & 93 & $-0.1(-0.5$ to 0.4$)$ & 98 & $0.2(-0.3$ to 0.7$)$ & 96 & $0.1(-0.4$ to 0.5$)$ \\
\hline African-American & 67 & $-0.1(-0.7$ to 0.5$)$ & 75 & $0.2(-0.4$ to 0.8$)$ & 74 & $0.1(-0.4$ to 0.6$)$ \\
\hline White & 25 & $0.1(-0.4$ to 0.7$)$ & 22 & $0.0(-0.6$ to 0.6$)$ & 21 & $0.1(-0.6$ to 0.7$)$ \\
\hline No Diabetes (all) & 156 & $0.5(0.3 \text { to } 0.7)^{\star \star \star}$ & 155 & $0.8(0.5 \text { to } 1.1)^{\star \star \star}$ & 154 & $0.6(0.3 \text { to } 0.9)^{* * *}$ \\
\hline African-American & 101 & $0.5(0.2 \text { to } 0.8)^{\star \star}$ & 103 & $0.8(0.4 \text { to } 1.1)^{\star \star \star}$ & 103 & $0.6(0.2 \text { to } 0.9)^{\star \star}$ \\
\hline White & 53 & $0.5(0.0 \text { to } 0.9)^{\star}$ & 51 & $0.8(0.3 \text { to } 1.2)^{\star \star \star}$ & 50 & $0.6(0.2 \text { to } 1.1)^{\star \star}$ \\
\hline Summary score for drinks, desserts, snacks & 236 & $1.1(0.9 \text { to } 1.3)^{\star \star \star}$ & 229 & $1.3(1.1 \text { to } 1.6)^{\star \star \star}$ & 228 & $1.1(0.8 \text { to } 1.3)^{\star \star *}$ \\
\hline Diabetes (all) & 87 & $1.1(0.7 \text { to } 1.4)^{\star \star \star}$ & 87 & $1.2(0.8 \text { to } 1.6)^{\star \star \star}$ & 85 & $0.9(0.5 \text { to } 1.3)^{* * *}$ \\
\hline African-American & 61 & $1.1(0.7 \text { to } 1.6)^{\star \star \star}$ & 64 & $1.3(0.8 \text { to } 1.7)^{\star \star \star}$ & 63 & $1.1(0.7 \text { to } 1.6)^{\star \star *}$ \\
\hline White & 25 & $1.0(0.5 \text { to } 1.5)^{\star \star \star}$ & 22 & $1.1(0.3 \text { to } 1.8)^{\star \star}$ & 21 & $0.1(-0.7$ to 1.0$)$ \\
\hline No diabetes (all) & 149 & $1.1(0.8 \text { to } 1.5)^{\star \star \star}$ & 142 & $1.4(1.1 \text { to } 1.8)^{\star \star \star}$ & 143 & $1.2(0.8 \text { to } 1.5)^{\star \star *}$ \\
\hline African-American & 95 & $1.3(0.9 \text { to } 1.8)^{\star \star \star}$ & 93 & $1.7(1.2 \text { to } 2.1)^{\star \star \star}$ & 96 & $1.3(0.9 \text { to } 1.8)^{* * *}$ \\
\hline White & 52 & $0.7(0.2 \text { to } 1.2)^{\star \star}$ & 48 & $0.9(0.4 \text { to } 1.4)^{\star \star \star}$ & 46 & $0.8(0.3 \text { to } 1.3)^{\star \star}$ \\
\hline \multicolumn{7}{|l|}{ Physical activity } \\
\hline Walking time, $\min / \mathrm{wk}$ & 249 & $64(19 \text { to } 109)^{\star \star}$ & 253 & $71(28 \text { to } 113)^{\star \star}$ & 250 & $22(-13$ to 56$)$ \\
\hline Diabetes (all) & 93 & $101(17 \text { to } 184)^{\star}$ & 98 & $126(58 \text { to } 194)^{\star \star \star}$ & 96 & $62(11 \text { to } 113)^{\star}$ \\
\hline African-American & 67 & $119(18 \text { to } 221)^{*}$ & 75 & $136(52 \text { to } 220)^{\star \star}$ & 74 & $75(13 \text { to } 137)^{*}$ \\
\hline White & 25 & $71(-81$ to 223$)$ & 22 & $117(14 \text { to } 219)^{\star}$ & 21 & $38(-36$ to 112$)$ \\
\hline No diabetes (all) & 156 & $42(-9$ to 94$)$ & 155 & $36(-17$ to 89$)$ & 154 & $-3(-49$ to 42$)$ \\
\hline African-American & 101 & $29(-45$ to 103$)$ & 103 & $19(-53$ to 91$)$ & 103 & $-17(-82$ to 47$)$ \\
\hline White & 53 & $63(8 \text { to } 118)^{*}$ & 51 & $68(-3$ to 138$)$ & 50 & $22(-22$ to 66$)$ \\
\hline Total physical activity time, min/wk & 249 & $97(36 \text { to } 158)^{\star \star}$ & 253 & $83(30 \text { to } 136)^{\star \star \star}$ & 250 & $48(-7$ to 103$)$ \\
\hline Diabetes (all) & 93 & $120(19 \text { to } 221)^{*}$ & 98 & $109(29 \text { to } 188)^{\star \star}$ & 96 & $62(-8$ to 131$)$ \\
\hline African-American & 67 & $136(17 \text { to } 255)^{*}$ & 75 & $127(32 \text { to } 223)^{\star \star}$ & 74 & $89(3 \text { to } 175)^{*}$ \\
\hline White & 25 & $106(-94$ to 305$)$ & 22 & $74(-63$ to 212$)$ & 21 & $-5(-91$ to 81$)$ \\
\hline No Diabetes (all) & 156 & $83(6 \text { to } 159)^{\star}$ & 155 & $67(-3$ to 137$)$ & 154 & $40(-39$ to 118$)$ \\
\hline African-American & 101 & $86(-17$ to 189$)$ & 103 & $37(-42$ to 116$)$ & 103 & $28(-76$ to 132$)$ \\
\hline White & 53 & 79 (-33 to 192$)$ & 51 & $125(-15$ to 265$)$ & 50 & $58(-55$ to 171$)$ \\
\hline
\end{tabular}

Significance level:

${ }^{*} p<0.05 ;{ }^{* *} p<0.01 ;{ }^{* \star *} p<0.001$.

DRA, dietary risk assessment; min, minute; wk, week.

Percentages of participants with diabetes who achieved $\geq 5 \%$ weight loss at 24 months, by Phase II intervention group, were (data not shown): 44\% (95\% CI 21 to 68) for the group weight loss program $(n=18) ; 24 \% \quad(95 \%$ CI 7 to 41$)$ for the combination weight loss program $(n=25)$; and $36 \%$ (95\% CI 22 to 50) for the maintenance of lifestyle intervention program.
At the conclusion of Phase I, 85 of 88 (97\%) participants with diabetes and 151 of 154 (98\%) without diabetes either strongly agreed or agreed that they would recommend the lifestyle program to others. After Phase II, among participants completing the acceptability survey with diabetes, all in the group weight loss program $(n=12)$ and 16 of $19(84 \%)$ in the combination 
Table 3 Change in physiological outcomes by diabetes status and race from baseline to 6,12 , and 24 months

\begin{tabular}{|c|c|c|c|c|c|c|}
\hline Outcome & $\mathbf{n}$ & $\begin{array}{l}\text { Phase } 1 \\
\text { Baseline to } 6 \text { months } \\
\text { Mean, } 95 \% \mathrm{Cl}\end{array}$ & $\mathbf{n}$ & $\begin{array}{l}\text { Phase } 2 \\
\text { Baseline to } 12 \text { months } \\
\text { Mean, } 95 \% \mathrm{Cl}\end{array}$ & $\mathbf{n}$ & $\begin{array}{l}\text { Phase } 3 \\
\text { Baseline to } 24 \text { months } \\
\text { Mean, } 95 \% \mathrm{Cl}\end{array}$ \\
\hline Systolic BP, mm Hg & 249 & $-6.4(-8.7 \text { to }-4.1)^{\star \star \star}$ & 251 & $-6.2(-9.0 \text { to }-3.3)^{\star \star \star}$ & 250 & $-7.3(-9.9 \text { to }-4.6)^{\star \star \star}$ \\
\hline Diabetes (all) & 93 & $-7.1(-11.3 \text { to }-3.0)^{\star \star \star}$ & 97 & $-5.8(-10.9 \text { to }-0.6)^{*}$ & 96 & $-7.4(-11.9 \text { to }-3.0)^{\star \star}$ \\
\hline African-American & 67 & $-8.6(-13.9 \text { to }-3.2)^{\star \star}$ & 74 & $-6.4(-12.7 \text { to }-0.1)^{\star}$ & 74 & $-9.3(-14.6 \text { to }-4.0)^{\star \star \star}$ \\
\hline White & 25 & $-3.8(-9.6$ to 2.0$)$ & 22 & $-4.1(-13.2$ to 5.0$)$ & 21 & $-0.4(-8.7$ to 8.0$)$ \\
\hline No diabetes (all) & 156 & $-5.9(-8.7 \text { to }-3.2)^{\star \star *}$ & 154 & $-6.4(-9.7 \text { to }-3.1)^{\star \star \star}$ & 154 & $-7.1(-10.5 \text { to }-3.8)^{\star \star \star}$ \\
\hline African-American & 101 & $-5.6(-8.9 \text { to }-2.2)^{\star \star}$ & 102 & $-7.3(-11.6 \text { to }-3.1)^{\star \star \star}$ & 103 & $-7.9(-12.2 \text { to }-3.5)^{\star \star \star}$ \\
\hline White & 53 & $-6.5(-11.3 \text { to }-1.7)^{\star *}$ & 51 & $-4.3(-9.5$ to 0.8$)$ & 50 & $-5.6(-10.7 \text { to }-0.5)^{\star}$ \\
\hline Diastolic BP, mm Hg & 249 & $-3.7(-4.9 \text { to }-2.5)^{\star \star \star}$ & 251 & $-5.0(-6.4 \text { to }-3.6)^{\star * *}$ & 250 & $-6.7(-8.3 \text { to }-5.2)^{\star \star \star}$ \\
\hline Diabetes (all) & 93 & $-4.4(-6.4 \text { to }-2.3)^{\star \star \star}$ & 97 & $-5.6(-8.2 \text { to }-3.0)^{\star * *}$ & 96 & $-7.2(-10.1 \text { to }-4.3)^{\star \star \star}$ \\
\hline African-American & 67 & $-4.6(-7.2 \text { to }-2.1)^{\star \star \star}$ & 74 & $-5.8(-8.8 \text { to }-2.7)^{\star \star \star}$ & 74 & $-8.2(-11.7 \text { to }-4.7)^{\star \star \star}$ \\
\hline White & 25 & $-4.1(-7.6 \text { to }-0.7)^{\star}$ & 22 & $-4.7(-10.0$ to 0.6$)$ & 21 & $-3.3(-8.3$ to 1.7$)$ \\
\hline No diabetes (all) & 156 & $-3.4(-4.8 \text { to }-1.9)^{\star \star \star}$ & 154 & $-4.6(-6.2 \text { to }-3.0)^{\star * *}$ & 154 & $-6.4(-8.2 \text { to }-4.7)^{\star \star \star}$ \\
\hline African-American & 101 & $-2.8(-4.8 \text { to }-0.9)^{\star \star}$ & 102 & $-4.8(-7.0 \text { to }-2.7)^{\star \star *}$ & 103 & $-6.5(-8.9 \text { to }-4.0)^{\star \star \star}$ \\
\hline White & 53 & $-4.3(-6.5 \text { to }-2.1)^{\star \star *}$ & 51 & $-3.9(-6.2 \text { to }-1.6)^{\star \star *}$ & 50 & $-6.3(-8.5 \text { to }-4.1)^{\star * *}$ \\
\hline Weight, kg & 248 & $-0.7(-1.2 \text { to }-0.3)^{\star \star}$ & 250 & $-1.7(-2.5 \text { to }-1.0)^{\star \star *}$ & 247 & $-1.6(-2.5 \text { to }-0.8)^{\star * *}$ \\
\hline Diabetes (all) & 92 & $-1.2(-2.1 \text { to }-0.4)^{\star \star}$ & 96 & $-1.5(-2.9 \text { to }-0.2)^{*}$ & 93 & $-3.7(-5.2 \text { to }-2.1)^{\star \star *}$ \\
\hline African-American & 66 & $-1.1(-2.0 \text { to }-0.3)^{\star \star}$ & 73 & $-1.0(-2.5$ to 0.4$)$ & 71 & $-3.1(-4.6 \text { to }-1.5)^{\star \star \star}$ \\
\hline White & 25 & $-1.6(-4.0$ to 0.7$)$ & 22 & $-3.3(-6.9$ to 0.4$)$ & 21 & $-5.5(-9.9 \text { to }-1.2)^{\star}$ \\
\hline No diabetes (all) & 156 & $-0.4(-0.9$ to 0.1$)$ & 154 & $-1.8(-2.7 \text { to }-1.0)^{\star \star *}$ & 154 & $-0.4(-1.4$ to 0.6$)$ \\
\hline African-American & 101 & $-0.7(-1.4$ to 0.0$)$ & 102 & $-2.2(-3.4 \text { to }-1.1)^{\star * *}$ & 103 & $-0.9(-2.2$ to 0.4$)$ \\
\hline White & 53 & $0.2(-0.5$ to 0.8$)$ & 51 & $-1.0(-2.3$ to 0.4$)$ & 50 & $0.9(-0.8$ to 2.5$)$ \\
\hline$\geq 5 \%$ weight loss, $\%$ & 248 & 9.3 (5.6 to 12.9$)$ & 250 & $23.2(17.9$ to 28.5$)$ & 247 & $23.1(17.8$ to 28.4$)$ \\
\hline Diabetes (all) & 92 & $10.9(4.5$ to 17.3$)$ & 96 & 20.8 (12.7 to 29$)$ & 93 & 34.4 (24.7 to 44.1$)$ \\
\hline African-American & 66 & 12.1 (4.1 to 20.2 ) & 73 & 19.2 (10.0 to 28.4$)$ & 71 & $32.4(21.3$ to 43.5$)$ \\
\hline White & 25 & 8.0 (0.0 to 18.8$)$ & 22 & 27.3 (8.3 to 46.2$)$ & 21 & 38.1 (16.9 to 59.3$)$ \\
\hline No diabetes (all) & 156 & 8.3 (4.0 to 12.7$)$ & 154 & 24.7 (17.8 to 31.5$)$ & 154 & 16.2 (10.4 to 22.1$)$ \\
\hline African-American & 101 & $11.9(5.5$ to 18.3$)$ & 102 & 26.5 (17.8 to 35.1$)$ & 103 & 18.5 (10.9 to 26.0$)$ \\
\hline White & 53 & 1.9 (0.0 to 5.6$)$ & 51 & 19.6 (8.6 to 30.6$)$ & 50 & $10.0(1.6$ to 18.4$)$ \\
\hline $\mathrm{HbA} 1 \mathrm{c}, \% \dagger$ & 217 & $0.01(-0.09$ to 0.12$)$ & 220 & $-0.07(-0.20$ to 0.06$)$ & & \\
\hline Diabetes (all) & 80 & $-0.11(-0.38$ to 0.17$)$ & 84 & $-0.30(-0.63$ to 0.02$)$ & & \\
\hline African-American & 60 & $-0.10(-0.45$ to 0.25$)$ & 66 & $-0.33(-0.72$ to 0.06$)$ & & \\
\hline White & 19 & $-0.20(-0.60$ to 0.20$)$ & 17 & $-0.28(-0.85$ to 0.28$)$ & & \\
\hline No diabetes (all) & 137 & $0.08(0.04 \text { to } 0.11)^{\star * *}$ & 136 & $0.07(0.01 \text { to } 0.13)^{\star}$ & & \\
\hline African-American & 87 & $0.10(0.05 \text { to } 0.14)^{\star * \star}$ & 88 & $0.08(0.01 \text { to } 0.16)^{\star}$ & & \\
\hline White & 48 & $0.05(0.00$ to 0.10$)$ & 47 & $0.05(-0.03$ to 0.13$)$ & & \\
\hline $\mathrm{HbA} 1 \mathrm{c}, \mathrm{mmol} / \mathrm{mol} \dagger$ & 217 & $0.1(-1.0$ to 1.3$)$ & 220 & $-0.8(-2.2$ to 0.7$)$ & & \\
\hline Diabetes (all) & 80 & $-1.2(-4.2$ to 1.9$)$ & 84 & $-3.3(-6.9$ to 0.2$)$ & & \\
\hline African-American & 60 & $-1.1(-4.9$ to 2.7$)$ & 66 & $-3.6(-7.9$ to 0.7$)$ & & \\
\hline White & 19 & $-2.2(-6.6$ to 2.2$)$ & 17 & $-3.1(-9.3$ to 3.1$)$ & & \\
\hline No diabetes (all) & 137 & $0.9(0.4 \text { to } 1.2)^{\star \star \star}$ & 136 & $0.8(0.1 \text { to } 1.4)^{\star}$ & & \\
\hline African-American & 87 & $1.1(0.5 \text { to } 1.5)^{\star \star \star}$ & 88 & $0.9(0.1 \text { to } 1.7)^{*}$ & & \\
\hline White & 48 & $0.5(0.0$ to 1.1$)$ & 47 & $0.5(-0.3$ to 1.4$)$ & & \\
\hline Total cholesterol, mg/dL $\ddagger$ & & & 221 & $-3.2(-7.0$ to 0.7$)$ & 211 & $-3.1(-7.8$ to 1.7$)$ \\
\hline Diabetes (all) & & & 84 & $0.4(-6.7$ to 7.6$)$ & 83 & $-4.2(-13.1$ to 4.6$)$ \\
\hline African-American & & & 66 & $-0.4(-8.3$ to 7.6$)$ & 65 & $-7.1(-17.5$ to 3.4$)$ \\
\hline White & & & 17 & $6.9(-9.5$ to 23.3$)$ & 17 & $9.1(-6.6$ to 24.8$)$ \\
\hline No diabetes (all) & & & 137 & $-5.4(-9.8 \text { to }-1.1)^{\star}$ & 128 & $-2.3(-7.7$ to 3.0$)$ \\
\hline African-American & & & 89 & $-6.8(-11.8 \text { to }-1.8)^{\star *}$ & 83 & $-2.4(-8.9$ to 4.2$)$ \\
\hline White & & & 47 & $-2.5(-11.0$ to 6.0$)$ & 44 & $-2.2(-11.6$ to 7.2$)$ \\
\hline HDL cholesterol, mg/dL $\ddagger$ & & & 220 & $-1.6(-2.8 \text { to }-0.4)^{*}$ & 211 & $-1.0(-2.3$ to 0.3$)$ \\
\hline Diabetes (all) & & & 84 & $-2.0(-4.0 \text { to } 0.0)^{*}$ & 83 & $-2.1(-4.4$ to 0.3$)$ \\
\hline African-American & & & 66 & $-1.4(-3.7$ to 0.8$)$ & 65 & $-2.2(-4.8$ to 0.5$)$ \\
\hline White & & & 17 & $-3.9(-8.7$ to 0.8$)$ & 17 & $-1.8(-7.6$ to 4.0$)$ \\
\hline No diabetes (all) & & & 136 & $-1.3(-2.8$ to 0.2$)$ & 128 & $-0.3(-1.7$ to 1.2$)$ \\
\hline African-American & & & 88 & $-1.6(-3.6$ to 0.4$)$ & 83 & $-0.1(-2.1$ to 2.0$)$ \\
\hline White & & & 47 & $-0.9(-3.1$ to 1.2$)$ & 44 & $-0.6(-2.6$ to 1.3$)$ \\
\hline
\end{tabular}

Significance level:

${ }^{*} p<0.05 ;{ }^{* *} p<0.01 ;{ }^{* *} p<0.001$.

$+\mathrm{HbA} 1 \mathrm{c}$ was not measured at 24 months.

łLipids were not measured at 6 months.

$\mathrm{BP}$, blood pressure; HbA1c, glycated hemoglobin; HDL, high-density lipoprotein. 
Figure $2 \mathrm{~N}$ and percentage of participants, by diabetes status, for weight change from baseline to follow-up at 6,12 , and 24 months. Weight change is shown for three cut points $(\geq 2.5$, $\geq 5$, and $\geq 7.5 \%$ of baseline weight). $\mathrm{N}$, number. $\geq 2.5 \%$ weight change

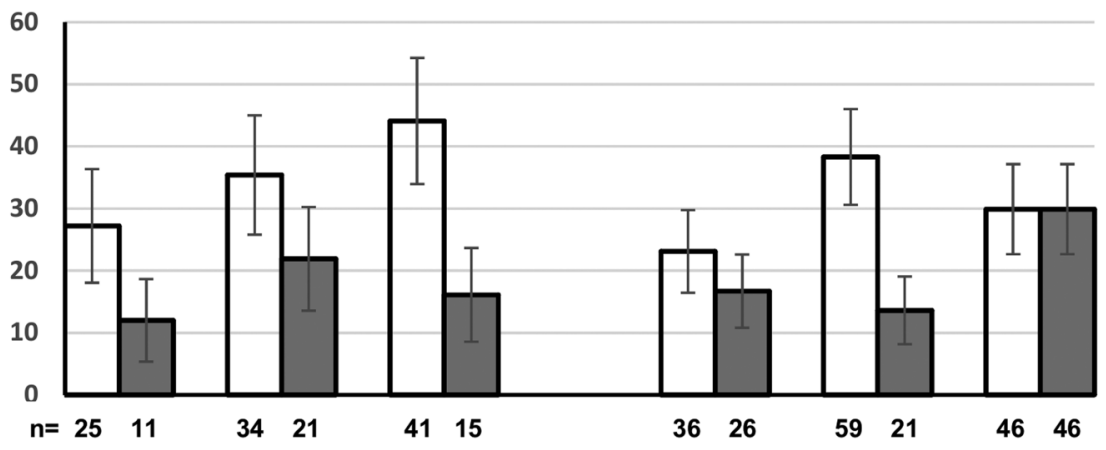

$\geq 5 \%$ weight change

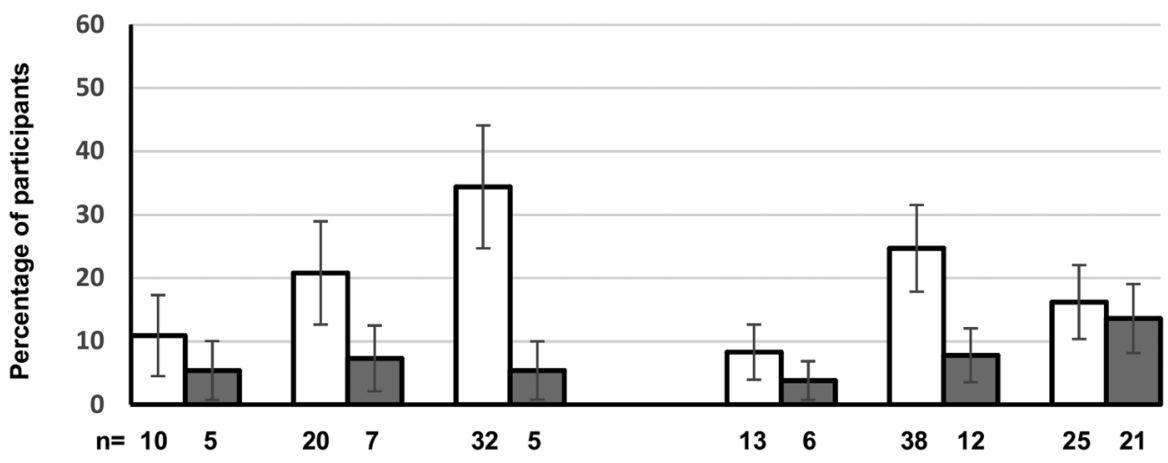

$\geq 7.5 \%$ weight change

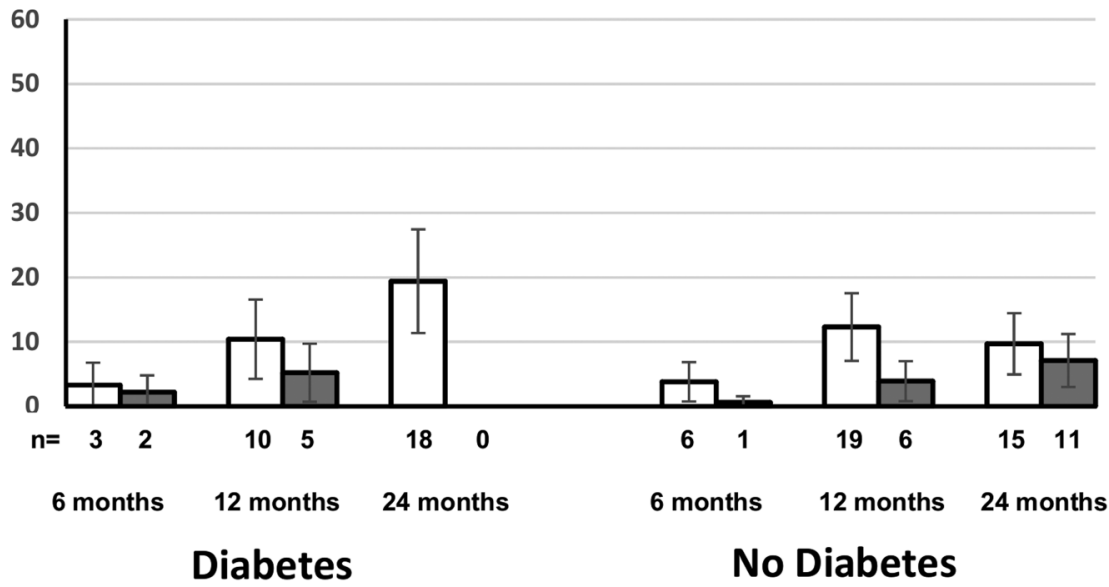

weight loss program were satisfied or very satisfied with the intervention. Participants without diabetes were similarly satisfied. In addition, no adverse outcomes were attributed to the intervention.

\section{CONCLUSIONS}

This study evaluated a lifestyle and weight loss intervention promoting a Mediterranean-style diet in a way that was designed to be appealing to residents of the southeastern USA residing in the 'stroke belt,' where the population's CVD risk is very high. Though this type of dietary intervention has been carefully evaluated in
Europe, ${ }^{7}$ it has not been adapted for and assessed in low-income and minority US populations. In this study, the intervention was well received by participants and, compared with baseline, there was improvement in selfreported lifestyle behaviors, BP, and weight, with substantially greater sustained weight loss observed for participants with diabetes.

Among participants with diabetes, our intervention did not achieve the same degree of weight loss documented in the Diabetes Prevention Program (DPP) study, ${ }^{34}$ which was $>5 \mathrm{~kg}$ at 24 months (20\% of participants were African-American, average age 51). However, in the small subgroup of participants $(n=25)$ who 
selected the group-based weight loss option, weight loss at 24 months was $>5 \mathrm{~kg}$, as it was for all of the white participants with diabetes. In essence, among participants selecting the group-based weight loss format, weight loss at 24 months in our low-income and high-minority population was similar to that observed in the DPP. Moreover, weight loss among all participants with diabetes was greater than in most weight loss studies enrolling disadvantaged population groups. ${ }^{4}$

Different from the PREDIMED study, which reported weight loss $<0.5 \mathrm{~kg}$ at 24 months follow-up in all study arms (all participants, not stratified by diabetes status), ${ }^{35}$ participants in our study with diabetes who selected the lifestyle only option (which focused on diet quality and physical activity, but not weight loss) lost $3.8 \mathrm{~kg}$ at 24-month follow-up. A possible explanation for weight loss in this group of our study, as compared with PREDIMED, is difference in baseline diet, with more poor quality carbohydrates and processed food in the American diet compared with the European $\operatorname{diet}^{36}$ and particularly so in the southeastern USA. ${ }^{37-40}$ In this setting of excess intake of poor quality carbohydrates, a change to a Mediterranean-style, unrestricted fat diet, may have positive metabolic and appetite-suppressing effects, as recently outlined by Ludwig. ${ }^{41}$ Although the dietary pattern advocated in this study was similar to the PREDIMED intervention arms (especially the nut intervention arm), ${ }^{7}$ we recommended regular consumption of vegetable oils (high in polyunsaturated and monounsaturated fats) as opposed to four tablespoons of extra virgin olive oil per day as tested in the PREDIMED olive oil intervention arm. In this regard, it is worth noting a recent publication assessing outcomes in two large cohort studies which indicated diets higher in polyunsaturated and monounsaturated fats are associated with a reduction in CVD mortality and total mortality. ${ }^{26}$

As illustrated in figure 2, among all participants with diabetes, including the majority who did not elect to take part in the weight loss intervention offered in Phase II of the intervention, weight loss increased steadily over the 24-month study period. This weight loss began during Phase I, which focused on diet quality and physical activity, but not specifically on weight loss, and continued at about the same rate during Phases II and III. The observed pattern of weight loss in this study was different from that observed in most other weight loss studies, which is usually greatest weight loss in the short term (6-12 months) with attenuation of weight loss beyond 1 year. ${ }^{42}$ In a recent meta-analysis of weight loss among named weight loss diet programs, only one of 10 programs achieved greater weight loss at 12 months than at 6 months. ${ }^{6}$ Even in programs with intensive interventions that include maintenance of weight loss components such as the $\mathrm{DPP}^{43}$ and Look AHEAD, ${ }^{8}$ there was attenuation in weight loss at 18 and 24 months, respectively. A possible explanation for the observed sustained weight loss in our study was that all participants received some level of intervention over 24 months and unlike most weight loss studies, which try to achieve weight loss over 6 months, our approach was to focus on weight loss over a longer time frame. Additionally, the Mediterranean dietary pattern may have contributed to the sustained weight loss over 24 months, as this dietary pattern has previously been shown to be associated with maintenance of weight loss. ${ }^{44}$

This study has several limitations including a pre-post design without a control group. While the observed changes may be due to the intervention, they could also be due to other factors, including secular trends. However, sustained weight loss among adults is uncommon. For example, in the control groups of weight loss RCTs such as DPP and Look AHEAD, average weight loss at 24-month follow-up was $<1 \mathrm{~kg} .{ }^{8}{ }^{34}$ With regard to secular trends in North Carolina during the time frame of this study (2011 to 2014), there were no changes in the rates of overweight and obesity as assessed by the Centers for Disease Control and Prevention's behavioral risk factor surveillance system. ${ }^{45}$

Another major limitation is the sample size of this study, especially with regard to outcomes by intervention groups (group weight loss, combination weight loss, or maintenance of lifestyle intervention) and race. Further, because weight loss was less than expected at the end of Phase II, as discussed in detail elsewhere, ${ }^{11}$ the sample size for the 'embedded' RCT of weight loss maintenance was so small that we did not undertake a formal analysis of outcomes for this RCT. Another limitation is that lifestyle outcomes were self-reported and may have been exaggerated due to social desirability reporting bias. Finally, our findings may not be generalizable to populations different from the sample enrolled from one community in eastern North Carolina.

The cost-effectiveness of an intervention is a very important consideration for community-based and clinic-based weight loss programs. Without a control group, we did not undertake a cost-effectiveness analysis, which is another limitation of this study. However, we have previously reported a cost-effectiveness analysis for the group-based intervention format that we tested in Phase II, comparing it with a delayed intervention control group. ${ }^{46}$ In that study, in which the weight loss intervention was considered cost-effective (assuming weight loss could be sustained over time), weight loss at 6-month follow-up was $3.7 \mathrm{~kg}$ in the intervention group, very similar to the weight loss of $3.9 \mathrm{~kg}$ observed at the completion of Phase II for our participants with diabetes for our participants with diabetes who received the group-based intervention.

The study has several strengths. First, is the relatively unselected sample (few exclusion criteria were applied and no run-in period) which enhances its generalizability; second, it used a design that mimicked real-world situations, allowing participants to choose between two weight loss intervention formats or to focus on lifestyle change without weight loss as a goal; third, the follow-up was $74 \%$ at 24 months, which is a larger follow-up 
percentage and longer follow-up interval than reported in many weight loss studies; and fourth, physiological outcomes were obtained using standardized objective measures.

In this study, with a relatively unselected sample, largely minority and of lower socioeconomic status, the tested Mediterranean-style dietary pattern, a pattern associated with substantial reduction in CVD risk ${ }^{7}$ was very well received. Among participants with diabetes, there was sustained improvement in self-reported lifestyle behaviors, BP, and weight change at 24-month follow-up. Though the study did not have a control group, our findings confirm the acceptability of a Mediterranean-style dietary pattern among this very high-risk population and suggest that this dietary pattern may be associated with sustained weight loss. Further study of interventions promoting this dietary pattern is warranted in high-risk US populations with diabetes, including RCTs that assess intermediate outcomes and CVD events.

\author{
Author affiliations \\ ${ }^{1}$ Ambulatory Care Physician, Durham VA Medical Center, Durham, \\ North Carolina, USA \\ ${ }^{2}$ Department of Nutrition, Center for Health Promotion and Disease \\ Prevention, Gillings School of Global Public Health, University of North \\ Carolina, Chapel Hill, North Carolina, USA \\ ${ }^{3}$ Center for Health Promotion and Disease Prevention, University of North \\ Carolina, Chapel Hill, North Carolina, USA \\ ${ }^{4}$ Department of Epidemiology, Gillings School of Global Public Health, \\ University of North Carolina, Chapel Hill, North Carolina, USA \\ ${ }^{5}$ Division of General Medicine and Clinical Epidemiology, School of Medicine, \\ University of North Carolina, Chapel Hill, North Carolina, USA
}

Acknowledgements We give special thanks to our Community Advisory Committee who provided helpful guidance with this project and to our study participants, whose willing participation made this study possible.

Contributors GGRE and TCK drafted the manuscript. CDS-H designed the study and developed the weight loss intervention. LFJ and ZG had full access to all the data and carried out the analysis. BAG supervised data collection. KRE developed the physical activity intervention. DAD acquired funding. ASA and TCK acquired funding and designed the study. All authors revised the manuscript and approved the final draft. TCK is the guarantor of this work and, as such, had full access to all the data in the study and takes responsibility for the integrity of the data and the accuracy of the data analysis.

Funding This research was supported by National Institutes of Health (NIH) grant 5P50 HL105184 to the University of North Carolina Center for Health Promotion and Disease Prevention (HPDP) with subcontract to the Brody School of Medicine, East Carolina University. Other support was provided by Centers for Disease Control and Prevention (CDC) cooperative agreement No. U48/DP001944 to HPDP (a CDC Prevention Research Center).

\section{Competing interests None declared.}

Ethics approval University of North Carolina at Chapel Hill biomedical IRB.

Provenance and peer review Not commissioned; externally peer reviewed.

Data sharing statement The data sets generated and/or analyzed during the current study are being prepared for web access on the BioLINCC repository, available at: https://biolincc.nhlbi.nih.gov/home/. Until available on this repository, the data are available from the corresponding author on reasonable request.
Open Access This is an Open Access article distributed in accordance with the Creative Commons Attribution Non Commercial (CC BY-NC 4.0) license, which permits others to distribute, remix, adapt, build upon this work noncommercially, and license their derivative works on different terms, provided the original work is properly cited and the use is non-commercial. See: http:// creativecommons.org/licenses/by-nc/4.0/

\section{REFERENCES}

1. American Diabetes Association. Foundations of care and comprehensive medical evaluation. Sec. 3 in standards of medical care in diabetes-2016. Diabetes Care 2016;39(Suppl 1):S23-35.

2. American Diabetes Association. Foundations of care: education, nutrition, physical activity, smoking cessation, psychosocial care, and immunization. Sec. 4 in standards of medical care in diabetes2015. Diabetes Care 2015;38 ():S20-30.

3. Franz MJ, Boucher JL, Rutten-Ramos S, et al. Lifestyle weight-loss intervention outcomes in overweight and obese adults with type 2 diabetes: a systematic review and meta-analysis of randomized clinical trials. J Acad Nutr Diet 2015;115:1447-63.

4. Harvey JR, Ogden DE. Obesity treatment in disadvantaged population groups: where do we stand and what can we do? Prev Med 2014;68:71-5.

5. Wadden TA, West DS, Neiberg $\mathrm{RH}$, et al. One-year weight losses in the Look AHEAD study: factors associated with success. Obesity (Silver Spring) 2009;17:713-22.

6. Johnston BC, Kanters S, Bandayrel K, et al. Comparison of weight loss among named diet programs in overweight and obese adults: a meta-analysis. JAMA 2014;312:923-33.

7. Estruch R, Ros E, Salas-Salvado J, et al. Primary prevention of cardiovascular disease with a Mediterranean diet. N Engl J Med 2013;368:1279-90.

8. Wing RR, Bolin P, Brancati FL, et al., Look Ahead Research Group. Cardiovascular effects of intensive lifestyle intervention in type 2 diabetes. N Engl J Med 2013;369:145-54.

9. Howard G, Labarthe DR, Hu J, et al. Regional differences in African Americans' high risk for stroke: the remarkable burden of stroke for Southern African Americans. Ann Epidemiol 2007;17:689-96.

10. Pitts SB, Vu MB, Garcia BA, et al. A community assessment to inform a multilevel intervention to reduce cardiovascular disease risk and risk disparities in a rural community. Fam Community Health 2013;36:135-46.

11. Keyserling TC, Samuel-Hodge CD, Pitts SJ, et al. A community-based lifestyle and weight loss intervention promoting a Mediterranean-style diet pattern evaluated in the stroke belt of North Carolina: the Heart Healthy Lenoir Project. BMC Public Health 2016;16:732.

12. Cooper LA, Ortega AN, Ammerman AS, et al. Calling for a bold new vision of health disparities intervention research. Am J Public Health 2015;105(Suppl 3):S374-6.

13. Centers for Disease Control and Prevention. Interactive Atlas of Heart Disease and Stroke. http://nccd.cdc.gov/DHDSPAtlas/ (accessed 29 Aug 2016).

14. Mozaffarian D, Benjamin EJ, Go AS, et al., Writing group members. Heart disease and stroke statistics-2016 update: a report from the American Heart Association. Circulation 2016;133:e38-360.

15. Keyserling TC, Samuel Hodge CD, Jilcott SB, et al. Randomized trial of a clinic-based, community-supported, lifestyle intervention to improve physical activity and diet: the North Carolina enhanced WISEWOMAN project. Prev Med 2008;46:499-510.

16. Samuel-Hodge CD, Johnston LF, Gizlice Z, et al. Randomized trial of a behavioral weight loss intervention for low-income women: the Weight Wise Program. Obesity (Silver Spring) 2009;17:1891-9.

17. Kraschnewski JL, Keyserling TC, Bangdiwala SI, et al. Optimized probability sampling of study sites to improve generalizability in a multisite intervention trial. Prev Chronic Dis 2010;7:A10.

18. Samuel-Hodge CD, Garcia BA, Johnston LF, et al. Translation of a behavioral weight loss intervention for mid-life, low-income women in local health departments. Obesity (Silver Spring) 2013;21:1764-73.

19. Halladay JR, Donahue KE, Hinderliter AL, et al. The Heart Healthy Lenoir project-an intervention to reduce disparities in hypertension control: study protocol. BMC Health Serv Res 2013;13:441.

20. Ammerman AS, Haines PS, DeVellis RF, et al. A brief dietary assessment to guide cholesterol reduction in low-income individuals: design and validation. J Am Diet Assoc 1991;91:1385-90.

21. Ammerman AS, DeVellis BM, Haines PS, et al. Nutrition education for cardiovascular disease prevention among low income populations: description and pilot evaluation of a physician-based model. Patient Educ Couns 1992;19:5-18. 
22. Jakobsen MU, O'Reilly EJ, Heitmann BL, et al. Major types of dietary fat and risk of coronary heart disease: a pooled analysis of 11 cohort studies. Am J Clin Nutr 2009;89:1425-32.

23. Mozaffarian D, Micha R, Wallace S. Effects on coronary heart disease of increasing polyunsaturated fat in place of saturated fat: a systematic review and meta-analysis of randomized controlled trials. PLoS Med 2010;7:e1000252.

24. Siri-Tarino PW, Sun Q, Hu FB, et al. Meta-analysis of prospective cohort studies evaluating the association of saturated fat with cardiovascular disease. Am J Clin Nutr 2010;91:535-46.

25. Sofi F, Abbate R, Gensini GF, et al. Accruing evidence on benefits of adherence to the Mediterranean diet on health: an updated systematic review and meta-analysis. Am J Clin Nutr 2010;92:1189-96.

26. Wang DD, Li Y, Chiuve SE, et al. Association of specific dietary fats with total and cause-specific mortality. JAMA Intern Med 2016;176:1134-45.

27. Samuel-Hodge CD, Garcia BA, Johnston LF, et al. Rationale, design, and sample characteristics of a practical randomized trial to assess a weight loss intervention for low-income women: The Weight-Wise II Program. Contemp Clin Trials 2012;33:93-103.

28. Steinberg DM, Tate DF, Bennett GG, et al. Daily self-weighing and adverse psychological outcomes: a randomized controlled trial. Am J Prev Med 2014;46:24-9.

29. Jilcott SB, Keyserling TC, Samuel-Hodge CD, et al. Validation of a brief dietary assessment to guide counseling for cardiovascular disease risk reduction in an underserved population. $J$ Am Diet Assoc 2007;107:246-55.

30. Block G, Gillespie C, Rosenbaum EH, et al. A rapid food screener to assess fat and fruit and vegetable intake. Am J Prev Med 2000;18:284-8.

31. Kraschnewski JL, Gold AD, Gizlice Z, et al. Development and evaluation of a brief questionnaire to assess dietary fat quality in low-income overweight women in the southern United States. J Nutr Educ Behav 2013;45:355-61.

32. Giles-Corti B, Timperio A, Cutt $\mathrm{H}$, et al. Development of a reliable measure of walking within and outside the local neighborhood: RESIDE's Neighborhood Physical Activity Questionnaire. Prev Med 2006;42:455-9.

33. Jones SA, Evenson KR, Johnston LF, et al. Psychometric properties of the modified RESIDE physical activity questionnaire among low-income overweight women. J Sci Med Sport 2014;18:37-42.
34. Knowler WC, Barrett-Connor E, Fowler SE, et al. Reduction in the incidence of type 2 diabetes with lifestyle intervention or metformin N Engl J Med 2002;346:393-403.

35. Estruch R, Martinez-Gonzalez MA, Corella D, et al. Effect of a high-fat Mediterranean diet on bodyweight and waist circumference: a prespecified secondary outcomes analysis of the PREDIMED randomised controlled trial. Lancet Diabetes Endocrinol 2016;4:666-76.

36. Kearney J. Food consumption trends and drivers. Philos Trans $R$ Soc Lond, B, Biol Sci 2010;365:2793-807.

37. Centers for Disease Control and Prevention. Fruit and vegetable consumption among adults-United States, 2005. MMWR Morb Mortal Wkly Rep 2007;56:213-7.

38. Blanck HM, Gillespie C, Kimmons JE, et al. Trends in fruit and vegetable consumption among U.S men and women, 1994-2005. Prev Chronic Dis 2008;5:A35

39. Krebs-Smith SM, Cook A, Subar AF, et al. US adults' fruit and vegetable intakes, 1989 to 1991: a revised baseline for the Healthy People 2000 objective. Am J Public Health 1995;85: 1623-9.

40. Serdula MK, Gillespie C, Kettel-Khan L, et al. Trends in fruit and vegetable consumption among adults in the United States: behavioral risk factor surveillance system, 1994-2000. Am J Public Health 2004;94:1014-8.

41. Ludwig DS. Always hungry? Conquer cravings, retrain your fat cells, and lose weight permanently. New York: Grand Central Publishing, 2016.

42. Heymsfield SB, Wadden TA. Mechanisms, pathophysiology, and management of obesity. N Engl J Med 2017;376:254-66.

43. Knowler WC, Fowler SE, Hamman RF, et al. Diabetes Prevention Program Research Group. 10-year follow-up of diabetes incidence and weight loss in the Diabetes Prevention Program Outcomes Study. Lancet 2009;374:1677-86.

44. Shai I, Schwarzfuchs D, Henkin Y, et al. Weight loss with a low-carbohydrate, Mediterranean, or low-fat diet. N Engl J Med 2008;359:229-41.

45. North Carolina State Center for Health Statistics. Annual Survey Results: Behavioral Risk Factor Surveillance System (BRFSS). http:// www.schs.state.nc.us/data/brfss/survey.htm. (accessed 7 Apr 2016).

46. Gustafson A, Khavjou O, Stearns SC, et al. Cost-effectiveness of a behavioral weight loss intervention for low-income women: the Weight-Wise Program. Prev Med 2009;49:390-5. 